\title{
PERAN AKTIVITAS SOSIAL DALAM MENINGKATKAN PENJUALAN USAHA AIR MINUM "X" DI DEMAK
}

\author{
Anisah $^{1}$ \\ Eviatiwi Kusumaningtyas Sugiyanto ${ }^{2}$
}

\author{
Anisahaja402@gmail.com ${ }^{1}$ \\ eviatiwisugiyanto@usm.ac.id ${ }^{2}$
}

Fakultas Ekonomi Universitas Semarang

Diterima: Mei 2020, Disetujui: Juni 2020, Dipublikasikan: Juli 2020

\begin{abstract}
This research was conducted in one of the Drinking Water Enterprises in Demak Regency related to the implementation of their social activities. The purpose of this study is to analyze the role of social activities to improving the sales performance of the drinking water business. This study uses a case study method, using source triangulation and method triangulation (observation, interviews, documentation). The selection of informants as sources of information is based on the principle of appropriateness and adequacy. The informants in this study consisted of key informants and supporting informants. The results show that social activity has a large influence on sales performance.
\end{abstract}

Keywords: Social Activities, Sales Performance, Drinking Water Enterprises

\begin{abstract}
ABSTRAK
Penelitian ini dilakukan di salah satu Usaha Air Minum di Kabupaten Demak terkait pelaksanaan aktivitas sosial. Tujuan penelitian ini adalah menganalisis peran aktivitas sosial dalam meningkatkan kinerja penjualan usaha air minum tersebut. Penelitian ini menggunakan metode studi kasus, dengan menggunakan triangulasi sumber dan triangulasi metode (observasi, wawancara, dokumentasi). Pemilihan informan sebagai sumber informasi didasarkan pada prinsip kesesuaian (appropriateness) dan kecukupan (adequacy). Informan dalam penelitian ini terdiri dari informan kunci dan informan pendukung. Hasil menunjukkan bahwa aktivitas sosial mempunyai pengaruh yang besar pada kinerja penjualan.
\end{abstract}

Kata Kunci: Aktivitas Sosial, Kinerja Penjualan, Usaha Air Minum

\section{PENDAHULUAN}

Salah satu alternative untuk meningkatkan kesejahteraan perusahaan adalah melalui aktivitas sosial. Aktivitas Sosial menjadi upaya perusahaan untuk membangun citra perusahaan baik di mata masayarakat, pemerintah dan stakeholder (karyawan, customer, shareholder, kreditor dan komunitasnya). Program aktivitas sosial merupakan operasi bisnis yang berkomitmen tidak hanya untuk meningkatkan 
keuntungan perusahaan secara finansial, melainkan untuk pembangunan sosial ekonomi karyawan secara holistic, melembaga dan berkelanjutan (Suharto, 2007).

Secara implementatif, perkembangan aktivitas sosial di Indonesia masih membutuhkan banyak perhatian bagi semua pihak, baik pemerintah, masyarakat luas dan perusahaan. Dalam UU aktivitas sosial telah menjadi satu bagian dalam aktivitas operasional perusahaan sehari-hari, sehingga pelaksanaannya perlu mendapatkan control dari manajemen (Freeman, 1984). Regulasi terkait aktivitas sosial atau yang biasa disebut dengan Corporate Social Responsibility (CSR) telah banyak ditetapkan seperti UU No.40 tahun 2007, No. 47 Tahun 2012, No, 25 tahun 2007, dan lain sebagainya menjadikan perusahaan berlomba-lomba untuk melaksanakan aktivitas tersebut. Maksud dan tujuan pelaksanaan aktivitas tersebut pun beragam mulai dari pembentukan citra positif sampai pada yang benar-benar melaksanakan secara sukarela tanpa mengharapkan imbal balik. Namun manfaat aktivitas sosial tidak dapat dipungkiri lagi bagi pengembangan citra positif di perusaahan, sesuai report dari Global CSR oleh Globescan (2007) yang menyatakan bahwa 72\% konsumen dari 10 negara bersedia membeli produk serta merekomendasikannya kepada orang lain, lantaran perusahaan telah melaksanakan aktivitas sosial. Dan dalam Majalah Marketing (2007) sebanyak 61\% konsumen memboikot produk-produk perusahaan yang enggan melaksanakan program CSR.

Beberapa penelitian juga telah mengungkap pentingnya tanggung jawab sosial bagi keberlangsungan hidup perusahaan diantaranya penelitian Zuhroh dalam Sukmawati (2003) yang menyatakan bahwa perusahaan dapat menggunakan informasi CSR sebagai competitive advantage-nya, Prasetya (2010), Hanifah (2016) juga menyatakan bahwa citra perusahaan dan loyalitas konsumen dapat ditinggaktan melalui CSR, lebih lanjut Indrawan (2011) menyatakan bahwa tanggung jawab sosial perusahaan berpengaruh pada kinerja perusahaan.

Pentingnya pengungkapan CSR atau aktivitas sosial mendorong perusahaan untuk mengukur pelaksanaannya apakah terbukti membawa manfaat untuk perusahaan atau tidak. Tentunya pelaksanaan aktivitas sosial antara perusahaan besar akan berbeda dengan dengan pelaksanaan aktivitas sosial pada usaha kecil, baik dari sisi program, dana, personil dan sebagainya. Bagi usaha kecil pelaksanaan aktivitas sosial 
diharapkan tidak mengganggu operasional perusahaannya. Salah satu usaha kecil di Kabupaten Demak yang rutin melaksanakan aktivitas sosial adalah Usaha Air Minum "X". Aktivitas-aktivitas sosial yang rutin dilaksanakan meliputi 1) bagi-bagi 5000 botol air minum kemasan bersama Komunitas Sedekah Air selama bulan Ramadhan, 2) Bagi-bagi 500-1000 botol air minum kemasan setiap hari jum'at di Masjid Agung Demak, Masjid Sayung, Masjid Bonang, Panti Asuhan. 3) Bagi-bagi botol air minum kemasan untuk Panti Asuhan dan Majelis Ta'lim terkait. Tentutany pelaksanaan aktivitas sosial tersebut disesuai dengan kemampuan perusahaan. Usaha Air Minum "X" di Demak menggunakan sumber daya alam sebagai bahan utamanya sehingga selalu berusaha menjadikan aktivitas sosial sebagai peranan utama dalam aktivitas bisnisnya. Dan pengusaha air minum tersebut berpendapat bahwa penerapan aktivitas sosial dapat meningkatkan kinerja penjualan perusahaan. Berikut ini data penjualan bersih yang diperoleh Usaha Air Minum "X" selama melaksanakan program aktivitas sosial.

Tabel 1 Penjualan Bersih bulan November 2018-Juni 2019

\begin{tabular}{|c|c|}
\hline Bulan & Penjualan Bersih \\
\hline November & 4.502 .500 \\
\hline Desember & 5.675 .000 \\
\hline Januari & 5.819 .000 \\
\hline Februari & 4.725 .000 \\
\hline Maret & 5.135 .500 \\
\hline April & 5.812 .000 \\
\hline Mei & 6.078 .000 \\
\hline Juni & 6.176 .000 \\
\hline
\end{tabular}

Sumber: Data Penjualan Usaha Air Minum "X" Demak

Dari data tersebut, penjualan Air Minum " $X$ " meningkat seiring dengan pelaksanaan program aktivitas sosial yang dilaksanakan. Pemilik usaha mengatakan turunnya penjualan pada bulan Februari 2019 dikarenakan terjadi masalah pada kualitas produk yang ditawarkan, promosi yang dilakukan oleh bagian pemasaran kurang mengena dihati konsumen, dan kondisi perekonomian masyarakat yang saat itu 
menurun sehingga menyebabkan omset penjualan juga menurun. Kegiatan aktivitas sosial penting bagi sebuah perusahaan karena hasil riset menyatakan konsumen lebih cenderung membeli produk yang memiliki kegiatan aktivitas sosial. Selain itu untuk menghindari perusahaan dari "gesekan" dengan masyarakat khususnya masyarakat lingkungan dimana perusahaan berada (Abidin, 2006). Dari uraian latar belakang diatas, maka peneliti bermaksud mengungkap peran aktivitas sosial dalam meningkatkan kinerja penjualan Usaha Air Minum di Demak. Adapun pertanyaan penelitiannya adalah 1) bagaimana pelaksanaan aktivitas sosial usaha air minum "X"? 2) Apa saja kontribusi program aktivitas sosial untuk usaha tersebut? 3) Bagaimana aktivitas sosial dapat meningkatkan kinerja penjualan usaha air minum " $\mathrm{X}$ ”?

\section{KAJIAN PUSTAKA}

\section{Stakeholder Theory}

Sepanjang tahun 1970an isu-isu terkait tanggung jawab sosial perusahaan telah mulai dikenal. Isu terkait tanggungjawab sosial perusahaan bersumber pada stakeholder theory. Teori Stakeholder berhubungan dengan kebijakan dan praktik, pemenuhan kebutuhan orang-orang yang terlibat dalam perusahaan, penghargaan terhadap masyarakat dan lingkungan serta sumbangsih dunia usaha untuk pembangunan berkelanjutan (Waryanti, 2009).

Stakeholder theory menjelaskan bahwa perusahaan tidak hanya bertanggung jawab terhadap para pemegang sahamnya tetapi juga bertanggung jawab pada pihakpihak yang berkepentingan daalam perusahaannya, perusahaan harus memberikan manfaat kepada pihak-pihak lain yang berkepentingan di luar para pemegang sahamnya. Pihak-pihak tersebut meliputi karyawan, konsumen, msayarakt dan lingkungan, kreditu, pemerintah, supplier dsb. Keberlangusngan hidup perusahaan memerlukan dukungan dari para stakeholdernya, sehingga aktivitas perusahaan dapat berjalan lancar karena perusahaan mendapatkan legalitas dari para stakeholdernya Januarti dan Apriyanti, 2005).

\section{Corporate Social Responsibility (SCR)}

Aktivitas sosial merupakan bagian dari pelaksanaan CSR. CSR sendiri didefinisikan sebagai wujud kegiatan sosial yang dilaksanakan sebagai upaya untuk menyeimbangkan antara kepentingan shareholder dan stakeholder lainnya (Susanto, 
2009). Beberapa alasan yang menjadikan perusahaan tersebut penting untuk melaksanakan tanggung jawab sosial adalah 1) membangun brand perusahaan (positioning brand), 2) penjualan meningkat, 3) pangsa pasar semakin luas, 4) loyalitas karyawan dan konsumen meningkat, 5) dapat menurunkan biaya operasional, 6) meningkatkan ketertarikan investor pada perusahaan (Philip Kotler dalam Solihin, 2009).

\section{Kinerja Penjualan}

Penjualan merupakan tujuan utama dilakukannya kegiatan perusahaan. Perusahaan dalam menghasilkan barang/jasa, mempunyai tujuan akhir yaitu menjual barang/jasa tersebut kepada masyarakat. Kinerja penjualan dapat dinyatakan secara kauntitas dengan volume penjualan yang menunjukkan segi fisik unit/volume dari suatu produk (Fredy Rangkuti, 2009). Peningkatan laba dapat diraih dengan peningkatan volume penjualan. Sehingga volume penjualan menjadi salah satu tolok ukur keberhasilan kinerja perusahaan. Berikut ini terdapat beberapa indikator dari volume penjualan yang dikutip dari Philip Kotler oleh Basu Swastha (2008) yaitu: 1) Mencapai volume penjualan, 2) Mendapatkan laba , 3) Menunjang pertumbuhan perusahaan

\section{METODE PENELITIAN}

Metode case study digunakan untuk mendapatkan gambaran apakah peran kegiatan aktivitas sosial mampu meningkatkan kinerja penjualan. Tahap berikutnya yaitu mengevaluasi dan menganalisis dari program tersebut. Tahap terakhir akan diperoleh kesimpulan dari peran aktivitas sosial dalam meningkatkan kinerja penjualan usaha air minum.

Tabel 2 Desain Penelitian

\begin{tabular}{ll}
\hline Dimension & \multicolumn{1}{c}{ Case Study } \\
\hline Focus & Analisis peran aktivitas sosial dalam meningkatkan \\
& kinerja penjualan Usaha Air Minum "X" Demak \\
& Demak \\
& Multiple source: Interview, Participant Observation, \\
Data Collection & Document
\end{tabular}


Data Analysis

Analisis, Interpretasi dan Penilaian

Product Of The Study

Studi mendalam tentang peran aktivitas sosial

Penelitian responden (informant) didasarkan pada prinsip kesesuaian (appropriateness) dan kecukupan (adequacy). Responden terdiri dari 3 orang pihak perusahaan, 2 orang penerima aktivitas sosial, dan 1 orang ahli/pakar pemasaran dari akademisi. Informasn dipilih dengan cara sengaja yang menjadi sasaran penelitian yaitu pihak-pihak yang menyatu dan mengetahu dengan benar obyek dan topik penelitian. Pihak perusahaan memiliki kompetensi langsung terhadap kasus yang dianalisis sehingga mempermudah peneliti mendapatkan informasi. Penerima aktivitas sosial sebagai informasi tambahan berasal dari anggota Komunitas Sedekah Air dan pegawai aparat perdesaan. Sedangkan pakar pemasaran dianggap mengetahui kegiatan yang biasa dilakukan oleh perusahaan.

Triangulasi sumber dan metode digunakan untuk menguji kualitas dan validitas data. Metode pengumpulan data terdiri dari wawancara, observasi dan dokumentasi. Wawancara mendalam dilakukan secara bebas terkontrol artinya wawancara dilakukan secara bebas sehingga data yang diperoleh adalah data yang luas dan mendalam, tetapi masih memperhatikan unsur terpimpin yang memungkinkan masih terpenuhinya prinsip komparabilitas dan reliabilitas secara langsung yang dapat diarahkan dan memihak pada persoalan- persoalan yang diteliti.

\section{ANALISIS DAN PEMBAHASAN}

\section{Pelaksanaan Aktivitas Sosial Usaha Air Minum "X di Demak}

Pelaksanaan Aktivitas Sosial Usaha Air Minum "X" melibatkan masyarakat sekitar sehingga masyarakat dapat memonitor kegiatan sosial yang sedang berlangsung. Selain itu pihak pemerintah juga ikut campur tangan dalam melakukan pengawasan terhadap pelaksanaan aktivitas sosial serta perlu adanya sanksi yang tegas jika suatu perusahaan tidak menjalankan kewajibannya dalam melaksanakan kegiatan soaial. Peraturan ini diatur dalam pasal 74 UU No 40 tahun 2007 tentang Perseroan Terbatas dan peraturan pemerintah sedangkan No 47 Tahun 2012 tentang Tanggung Jawab Sosial dan Lingkungan. 
Hal ini tersampaikan oleh Pemilik Usaha.

"Untuk pelaksanaan aktivitas sosial sendiri saya selalu bekerja sama dengan aparat pemerintah serta masyarakat sekitar yang nantinya bantuan tersebut akan dibagikan kepada masyarakat. Dalam pelaksanaannya sendiri, telah diatur dalam UU No.40 tahun 2007 tentang Perseroan Terbatas pasal 74 dimana pada butir pertama dijelaskan Perseroan yang menjalankan kegiatan usahanya di bidang dan/atau berkaitan dengan sumber daya alam wajib melaksanakan tanggung jawab sosial dan lingkungan. Selain kewajiban yang telah diatur oleh undang - undang setiap perusahaan kini bersaing secara sehat untuk menciptakan citra yang baik di mata masing - masing baik konsumen serta masyarakat sekitarnya. Kegiatan aktivitas sosial ini dilakukan tidak terlepas dari peran bagian pemasaran yang menjadi salah satu pengendali dari berbagai kegiatan sosial”.

(Hasil wawancara dengan Aya (nama samaran), pada tanggal 15 Juli 2019)

Pendapat tersebut juga disampaikan bagian pemasaran produk Usaha Air Minum "X”. Berikut penyampaiannya.

"Saat ini pihak perusahaan menerapkan program aktivitas sosial sejak pertama kali usaha ini mulai dirintis. Pelaksanaannya pihak perusahaan meminta izin kepada pemerintah setempat serta masyarakat terkait akan sumbangan yang diberikan apakah sesuai dengan barang yang diinginkan saat ini. Tidak hanya itu kami dari pihak perusahaan juga memberikan edukasi kepada masyarakat setempat akan pentingnya air kesehatan ini. Yang mana dari adanya edukasi tersebut mendorong masyarakat untuk membeli mesin air minum isi ulang. Pelaksanaan tanggung jawab sosial dilakukan melalui penggunaan sumber daya alam dan atau sumber daya manusia secara efisien untuk menghasilkan barang dan jasa dengan harga yang terjangkau oleh masyarakat”.

(Hasil wawancara dengan Lani (nama samaran), pada tanggal 15 Juli 2019)

Pelaksanaan aktivitas sosial; usaha air minum "X: mengacu pada hal-hal sebagai berikut:

UU No 40 Ps 74 Tahun 2007 ayat 1 sampai 4, menjelaskan bahwa :

1. Perseroan yang menjalankan kegiatan usahanya dibidang dan atau berkaitan 
dengan sumber daya alam wajib melaksanakan tanggung jawab social dan lingkungan. 2. Tanggung jawab social dan lingkungan sebagaimana pada ayat (1) merupakan kewajiban perseroan yang dianggarakan dan diperhitungkan sebagai biaya perseroan yang pelaksanaannya dilakukan dengan memperhatikan kepatutan dan kewajaran.

3. Perseroan yang tidak melaksanakan kewajiban sebagaimana dimaksud pada ayat (1) dikenai sanksi sesuai dengan ketentuan perundang- undangan.

4. Ketentuan lebih lanjut mengenai tanggung jawab social dan lingkungan diatur dengan Peraturan Pemerintah.

UU No 25 Ps 15 Tahun 2007 tentang Penanaman Modal menjelaskan bahwa setiap penanaman modal berkewajiban:

1. Menerapkan prinsip Corporate Governance yang baik.

2. Melaksanakan tanggung jawab social perusahaan.

3. Membuat laporantentangkegiatan penanaman modal dan menyampaikan kepada Badan Koordinasi Penanaman Modal.

4. Menghormati tradisi budaya masyarakat sekitar lokasi kegiatan penanaman modal.

5. Mematuhi semua ketentuan perundang-undangan.

Aktivitas sosial atau tanggung jawab sosial perusahaan sesuai penjelasan pasal dalam UU tersebut menjadi bagian operasional perusahaan guna menciptakan hubungan yang harmonis kepada para stakeholdernya, seiring mematuhi peraturanperaturan yang berlaku.

2. Pelaksanaan aktivitas sosial bekerja sama dengan aparat pemerintah serta masyarakat sekitar.

Pelaksanaan aktivitas sosial melibatkan masyarakat karena perusahaan mengetahui yang bisa membangun brand image perusahaan itu adalah masyarakat. Berkembangnya isu mengenai aktivitas sosial dan etika dalam berbisnis telah membuat perusahaan mulai sadar bahwa keberhasilan harus dibangun dari penghargaan dan kepercayaan masyarakat. Pengawasan oleh pemerintah dan masyarakat mendorong semakin banyak perusahaan mulai mengikuti peraturan dan 
menjadikan aktivitas sosial sebagai etika berbisnis. Menurut Tjipta (2006) aktivitas sosial dapat memberikan manfaat jangka panjang bagi perusahaan, yaitu akan berdampak pada pertumbuhan dan keuntungan perusahaan. Pelaksanaan aktivitas sosial menjadi konsekuensi bagi perusahaan demi pembangunan berkelanjutan.

3. Salah satu kegiatan untuk promosi.

Dalam Tjiptono (2002) promosi adalah bentuk komunikasi pemasaran artinya aktivitas pemasaran yang berusaha menyebarkan informasi, mempengaruhi/ membujuk dan atau mengingatkan pasar sasaran atau perusahaan dan produknya agar bersedia diterima, membeli dengan loyal pada produk yang ditawarkan perusahaan yang bersangkutan. Jadi promosi adalah upaya untuk memberitahukan produk atau jasa dengan tujuan menarik konsumen untuk membeli.

Adapun tujuan dari promosi adalah :

1. Untuk menyebarluaskan informasi suatu produk kepada calon konsumen yang potensial.

2. Untuk mendapatkan konsumen baru dan untuk menjaga loyalitas konsumen tersebut.

3. Untuk menaikkan penjualan serta laba/keuntungan.

4. Untuk membedakan atau mengunggulkan produknya dibandingkan dengan produk kompetitor.

\section{Kontribusi Program Aktivitas Sosial untuk Usaha Air Minum "X" Demak}

Berbagai upaya sudah dilakukan oleh Produsen Usaha Air Minum "X” yang mana dengan adanya kegiatan tersebut mampu memberikan kontribusi yang begitu besar bagi sebuah perusahaan. Seperti yang di sampaikan oleh Pemilik Usaha tersebut.

"Secara prinsip, aktivitas sosial yang kita laksanakan merupakan komitmen kita untuk berkontribusi dalam pembangunan ekonomi berkelanjutan, bekerja sama dengan karyawan, keluarga karyawan, dan masyarakat setempat (lokal) dalam rangka meningkatkan kualitas lingkungan masyakat. Kegiatan sosial tersebut tidak 
lain adalah sebagai bentuk timbal balik perusahaan terhadap masyarakat dan lingkungan. Perusahaan dalam proses produksinya selalu tergantung terhadap masyarakat dan lingkungan. Aktivitas sosial ini dilakukan agar kelangsungan perusahaan tetap terjamin dan mendapatkan citra positif dikalangan masyarakat. Terkait dengan dampak, keputusan, dan kegiatan di masyarakat dan lingkungan tersebut, melalui perilaku yang transparan dan etis yang memberikan kontribusi terhadap pembangunan berkelanjutan, kesehatan dan kesejahteraan masyarakat dan lingkungan”. (Hasil wawancara dengan Aya (nama samaran), pada tanggal 15 Juli 2019)

Dari segi informan ahli dalam bidang pemasaran mengungkapkan bahwa kontribusi dalam program aktivitas sosial salah satunya adalah meningkatkan citra perusahaan. Berikut pendapatnya.

"Tujuannya apa tujuannya ya untuk pembentukan citra, citra produk, citra perusahaan, ya intinya bagaimana menciptakan perusahaan itu mempunyai kesan positif dimata masyarakat. Tapi pada tahun 2005 ya kalo nggak salah itu ada undang-undang No 74 ya kalo nggak salah itu undang-undang mengenai perseroan terbatas itu yang mengatur bagaimana mereka diharuskan mempunyai tanggung jawab social, nah sehingga itu menyebabkan ramainya perusahaan itu untuk melakukan kegiatan sosial. Pada awalnya CSR ini yang pertama kali pada tahun 91 itu Sido Muncul ya melakukan kegiatan mudik lebaran. Sehingga Sido Muncul itu dianggap sebagai pioner untuk kegiatan mudik lebaran sampai sekarang masih terus berlanjut. Kemudian ada BUMN BUMN sekarang juga meniru apa yang dilakukan oleh PT. Sido Muncul ya untuk melakukan kegiatan sosial".

(Hasil wawancara dengan Tatak (nama samaran), pada tanggal 20 Juni 2019)

1. Berkontribusi dalam pembangunan ekonomi berkelanjutan.

Sebagai konsekuensi sosial pelaksanaan tanggungjawab sosial sangat perlu untuk dilaksanakan, tidak hanya bertujuan untuk meningkatkan keuntungan (Tjipta, 2006). Dalam hal ini aktivitas sosial merupakan komitmen perusahaan atau dunia bisnis untuk berkontribusi dalam pengembangan ekonomi yang berkelanjutan dengan memperhatikan tanggung jawab sosial perusahaan dan menitikberatkan pada keseimbangan antara perhatian terhadap aspek ekonomi, sosial, dan lingkungan (Untung, 2008). Akhir tahun 1980an diperkenalkan konsep sustainability development 
(pembangunan berkelanjutan) oleh The World Commision on Environment and Development, yang didefinisikan "pembangunan berkelanjutan adalah pembangunan yang dapat memenuhi kebutuhan manusia saat ini tanpa mengorbankan kemampuan generasi yang akan datang dalam memenuhi kebutuhan mereka”.

2. Meningkatkan kualitas lingkungan masyarakat.

Peningkatan kualitas lingkungan dalam masyarakat sekitar perusahaan dilakukan melalui pendekatan pelaksanaan aktivitas-aktivitas sosial. Usaha Air Minum "X" Demak berusaha mengedepankan konsep aktivitas sosial supaya lebih menekankan pembangunan sosial dan pembangunan kapasitas masyarakat sehingga mampu menggali potensi masyarakat lokal yang menjadi modal sosial perusahaan untuk maju dan berkembang. Untuk memelihara kualitas hidup jangka panjang terutama kualitas lingkungan, pelaksanaan aktivitas sosial banyak difokuskan pada kegiatan-kegiatan pelestarian lingkungan (Susanto, 2009).

3. Citra positif dikalangan masyarakat.

Citra positif terbentuk berdasarkan informasi-informasi yang diterima dalam masyarakat. Jika informasi yang diterima bagus dengan melaksanakan aktivitas sosial maka dengan sendirinya perusahaan mendapatakan nama baik. Salah satu manfaat yang dapat diperoleh dari pelaksanaan aktivitas sosial perusahaan adalah perusahaan mendapatkan pengakuan dan diterima di masyarakat, mendapaat dukungan dari komunitas, meminimalkan dampak buruk dari boikot, demo dan efek citra negative perusahaan (Susanto, 2009)

\section{Meningkatkan reputasi perusahaan.}

Pengungkapan (disclosure) aktivitas sosial telah banyak dilakukan perusahaan melalui berbagai media dalam laporan tahunan, website, media sosial seperti facebook, intagram dan lain sebagainya. Dengan pengungkapan tersebut perusahaan memperoleh banyak keuntungan diantaranya semakin luas dikenal masyarakat, meningkatnya kepercayaan konsumen, citra positif yang semakin meningkat. Hal tersebut menjadi 
investasi jangka panjang bagi perusahaan, karena dapat meningkatkan penjualan dan pada akhirnya meningkatkan laba perusahaan

\section{Memperkuat brand.}

Menurut Kotler (2005) merek merupakan janji penjual untuk secara konsisten memberikan tampilan, manfaat dan jasa tertentu pada pembeli. Tujuan pemberian merek adalah untuk mengidentifikasi produk atau jasa yang dihasilkan sehingga berbeda dari produk atau jasa yang dihasilkan oleh pesaing. Jadi Brand bukan sekedar logo atau nama perusahaan, melainkan image atau persepsi seseorang tentang produk atau perusahaan. Brand bagi sebuah perusahaan adalah reputasi bagi seseorang. Apabila suatu perusahaan memperlakukan merek hanya sekedar suatu nama, maka perusahaan tersebut tidak melihat tujuan merek sebenarnya.

\section{Pembentukan citra.}

Citra menurut Ardianto (2010) dalam buku Metodologi Penelitian untuk Publik Relations adalah serangkaian pengetahuan, pengalaman, perasaan (emosi) dan penilaian yang diorganisasikan dalam sistem kognisi manusia, atau pengetahuan pribadi yang sangat diyakini kebenarannya. Menurut Ardianto (2011) dalam buku Handbook of Publik Relations, citra adalah perasaan, gambaran diri publik terhadap perusahaan, organisasi atau lembaga, kesan yang dengan sengaja diciptakan dari suatu objek, orang atau organisasi. Usaha Air Minum "X" Demak berusaha mengedepankan citra. Citra sendiri merupakan berbagai pikiran atau opini masyarakat mengenai perusahaan tertentu. Aktivitas tersebut dapat berupa pelayanan kepada masyarakat, mengadakan kegiatan tertentu, baik kegiatan social maupun kegiatan lain. Menurut John Nimpoen (Ardianto, 2010) menjelaskan pola pembentukan citra ada 4 unsur yang saling berkaitan, yaitu persepsi, kognisi, motivasi dan sikap. Dimana satu dengan lainnya akan menimbulkan suatu respon tertentu atas stimulus yang telah diberikan, semua hal tersebut bermula dari pengalaman yang telah terbentuk pada masa sebelumnya mengenai citra perusahaan. 


\section{Citra produk.}

Citra produk adalah respon dari konsumen pada keseluruhan penawaran yang diberikan didefinisikan sebagai sejumlah kepercayaan, ide-ide, dan kesan masyarakat pada suatu image produk. Apabila produk dimata konsumen itu baik, maka langkah selanjutnya bagi perusahaan adalah mempertimbangkan harga, perbandingan dengan produk sejenis, manfaat, kemasan dan lain-lain. Usaha Air Minum "X" Demak mendapatkan respon positif dari masyarakat sekitar. Meskipun harganya terdengar mahal, namun banyak konsumen yang menyukai produk usaha air minum " $\mathrm{X}$ " bahkan tertarik ingin membuka usaha sendiri.

\section{Aktivitas Sosial dapat Meningkatkan Kinerja Penjualan}

Setelah mengetahui pelaksanaan dan kontribusi program aktivitas sosial Air minum isi ulang. Tentunya perusahaan mengerti apa saja keuntungan bagi perusahaan dimasa mendatang. Apakah dengan kegiatan ini bisa berdampak pada kinerja penjualan. Berikut ungkapan dari pemilik Air minum isi ulang Sayung Demak.

"Sejak dikeluarkannya Undang Undang mengenai aktivitas sosial membuat perusahaan semakin berbondong-bondong untuk melakukan kegiatan social ini. Dasar dari adanya kegiatan ini karena perusahaan memiliki beberapa alasan. Diantaranya bisa membangun positioning Brand, mendongkrak penjualan, memperluas pangsa pasar, meningkatkan loyalitas karyawan, mengurangi biaya operasional, serta meningkatkan daya tarik korporat dimata investor dan analis keuangan. Masyarakat sekitar sebagai penerima manfaat dapat meningkatkan kesejahteraan dan kualitas hidupnya, sedangkan perusahaan sebagai pelaksana mendapatkan timbal balik berupa penilaian positif bagi citra perusahaan dari seluruh masyarakat penerima manfaat sehingga pada akhirnya akan mendapatkan dukungan yang menjamin keberlangsungan perusahaan serta loyalitas konsumen sebagai bentuk penghargaan bagi perusahaan”.

(Hasil wawancara dengan Aya (nama samaran), pada tanggal 15 Juli 2019)

Pendapat tersebut juga disampaikan bagian pemasaran Air minum isi ulang Sayung Demak. Berikut penyampaiannya.

"Aktivitas sosial digunakan dalam strategi pemasaran salah satunya dimasukan kedalam bauran promosi melalui marketing komunikasi. Marketing komunikasi adalah 
media persuasif yang bertujuan membujuk calon konsumen menjadi konsumen potensial dalam jangka panjang. Dari konsumen potensial jangka panjang tersebut siklus penjualan Air minum isi ulang semakin lama semakin meningkat. Sehingga mendongkrak laba dan meningkatkan pertumbuhan ekonomi. Keberhasilan perusahaan dalam menghasilkan laba tidak bisa dilakukan tanpa adanya kepedulian perusahaan terhadap masyarakat dan taat terhadap hukum yang berlaku. Sebaiknya, kegiatan untuk menghasilkan laba dikaitkan dengan pengembangan masyarakat sekitar dan pembangunan yang berkelanjutan, karena masyarakat memegang peranan penting dalam keberlangsungan bisnis perusahaan".

(Hasil wawancara dengan Lani (nama samaran), pada tanggal 15 Juli 2019)

1. Aktivitas sosial bisa membangun merek, mendongkrak profit keuntungan, memperluas pangsa pasar.

Merek merupakan identitas bagi perusahaan, merek dapat berupa tanda symbol, rancangan atau kombinasi ketiganya, dan menjadi bagian penting bagi perusahaan untuk membedakannya dengan perusahaan lain (Rangkuti, 2009). Melalui merek, mayarakat dapat dengan mudah mengenal perusahaan, dan dengan merek pula dapat tercipta hubungan emosional antara konsumen dan perusahaan. dengan merek pula perusahaan dapat menguasai pasar. Untuk itu dalam pelaksanaan aktivitas sosial, perusahaan membawa merek produknya untuk lebih dikenal oleh masyarakat atau perusahaan menyumbang produknya sendiri untuk berderma. Sedangkan aktivitas yang dapat ditempuh untuk mendongkrak profit antara lain dengan meningkatkan produktivitas dan melakukan efisiensi biaya, sehingga perusahaan mempunyai keunggulan kompetitif yang dapat memberikan nilai tambah semaksimal mungkin (Wibisono, 2007).

\section{Meningkatkan loyalitas karyawan}

Karyawan akan merasa bangga bekerja pada perusahaan yang memiliki reputasi yang baik, yang secara konsisten melakukan upaya- upaya untuk membantu meningkatkan kesejahteraan dan kualitas hidup masyarakat dan lingkungan. Kebanggaan ini pada akhirnya akan menghasilkan loyalitas yang tinggi, sehingga mereka merasa lebih termotivasi untuk bekerja lebih keras demi kemajuan perusahaan. 
Selain melakukan aktivitas sosial untuk pihak luar perusahaan juga melaksanakan aktivitas sosial untuk pihak internal yaitu karyawan. Aktivitas sosial yang dilaksanakan yaitu menciptakan lingkungan kerja yang nyaman, jam kerja yang tidak membebankan karyawan. Aktivitas sosial tersebut dapat meningkatkan keterlibatan karyawan dalam perusahaan sehingga nantinya dapat meningkatkan loyalitas dan semangat kerja serta produktivitas karyawan.

3. Masyarakat sekitar sebagai penerima manfaat dapat meningkatkan kesejahteraan dan kualitas hidupnya.

Menurut Sulistyani (2004) pemberdayaan masyarakat bertujuan untuk membentuk individu dan masyarakat menjadi mandiri. Kemandirian tersebut melalui kemandirian berfikir, bertindak dan mengendalikan apa yang mereka lakukan. Kegiatan aktivitas-aktivitas sosial penting untuk disinkronkan dengan programprogram pemberdayaan dalam mayrakat seperti pemberian pelatihan, pengangkatan karyawan dari masyarakat sekitar dan sebagaunya. Tujuannya adalah agar masyarakat mampu meningkatkan kesejahteraan dan kualitas hidupnya.

4. Membangun investasi keuntungan tersendiri bagi perusahaan.

Aktivitas sosial yang dilakukan secara konsisten dapat mendatangkan keuntungan bagi perusahaan, karena aktivitas tersebut menjadi investasi jangka panjang bagi perusahaan (Lako, 2011). Masyarakat lebih menyukai produk-produk perusahaan yang memeperhatikan lingkungan sekitarnya. Dengan legalitas dari masyarakat tersebut perusahaan dapat secara lanjar menjalankan operasionalnya, tanpa ada gangguan dan pandangan negative dari masyarakat.

\section{SIMPULAN}

1. Pelaksanaan aktivitas sosial yang diterapkan oleh Usaha Air Minum "X" Demak merupakan gabungan dengan Komunitas Sedekah Air yang pelaksanaannya bekerja sama dengan aparat pemerintah serta masyarakat sekitar. Dalam menerapkan program tersebut, perusahaan tidak lepas dari UU No. 40 Pasal 74 tahun 2007 tentang Perseroan Terbatas. Selain itu, pihak perusahaan juga mengedukasi masyarakat 
setempat untuk berperan aktif dalam kegiatan ini. Edukasi tersebut menjadi wadah bagi perusahaan dalam kegiatan promosi.

2. Kontribusi yang diterima oleh perusahaan dalam menerapkan program aktivitas sosial diantaranya: Pembangunan ekonomi berkelanjutan yang berdampak meningkatkan kualitas lingkungan masyarakat, memperkuat brand, citra positif dikalangan masyarakat semakin meningkat, meningkatnya reputasi perusahaan, citra, citra produk, dan citra perusahaan.

3. Meningkatnya kinerja penjualan Usaha Air Minum "X" Demak dipengaruhi oleh program aktivitas sosial. Program aktivitas sosial mampu membangun merek, mendongkrak profit keuntungan, memperluas pangsa pasar, meningkatkan loyalitas karyawan dan membangun investasi menjadi keuntungan tersendiri usaha tersebut. Selain itu masyarakat sekitar juga menerima manfaat dengan meningkatnya kesejahteraan dan kualitas hidup mereka.

\section{DAFTAR PUSTAKA}

Ardianto, Elvinaro, 2011. Handbook Of PR (Public Relations): Penganta Komprehensif. Simbiosa Rekatama Media. Bandung

Dias Prasongko, 16 Juni 2012, Implementasi Program CSR yang Ideal, http://www.balairungpress.com/2012/06/implementasi-program-csr-yangideal/dipetik 30 Juni 2019.

Dikky Satia, 10 Januari 2016, Selamat Datang di Website Air minum isi ulang Indonesia, www.saykangenwater.com dipetik 20 Mei 2019.

Effendi, Muhammad Arief. 2009. The power Of Good Corporate Governance: Teori dan Implementasi. Salemba Empat. Jakarta

Firdaus Baderi, 21 Juli 2017, Peran CSR di Masyarakat, www.neraca.co.id/article/87711/peran-csr-di-masyarakat dipetik 30 Juni 2019.

Hadi, Nor.2011. Corporate Sosial Responsibility, Graha Ilmu. Yogyakarta 
Mediana Dessy, 22 November 2014, Corporate Sosial Responsibility (CSR) Sebagai Salah Satu Bukti Komitmen Dunia Usaha Dalam Mewujudkan PembangunanBerkelanjutan,www.kompasiana.com/mdessy/54f93524a3331 $1 \mathrm{f} 8478 \mathrm{~b} 4 \mathrm{cb} 2 /$ corporate- social-responsibility-csr-sebagai-salah-satu-buktikomitmen-dunia-usaha- dalam-mewujudkan-pembangunan-berkelanjutan dipetik 27 Juni 2019.

Murni Sri, Amin Jamal, Fitriyah Nur. 2015."Peranan Corporate Social Responsibility (CSR) dalam Meningkatkan Pembangunan Masyarakat Desa di Desa Lung Anai Kecamatan Loa Kulu” Vol 3. No.1 Hal 138- 147.

Pratama Satya Gede Wibi, Nurcaya Nyoman I (2016), "Pengaruh Corporate Social Responsibility Terhadap Ekuitas Merek yang di Mediasi oleh Citra Perusahaan" Vol. 5.No. 7 Hal 4253-4280.

Probosiwi Ratih (2016), "Tanggung Jawab Sosial Perusahaan dalam Peningkatan Kesejahteraan Masyarakat” Vol. 13.No. 2 Hal.30-40.

Ratu Firdaus Tifani, Idris. 2008. "Pengaruh Corporate Social Responsibility (CSR), Kualitas Pelayanan dan Promosi Terhadap Brand Image Telkomsel di Kota Padang" Vol. 1 No. 2. Hal 12 .

Sari Manika Dewa Ayu, Sinarwati Kadek Ni, Wahyuni Arie Made. 2017. "Implementasi Corporate Social Responsibility (CSR) dan Dampaknya Terhadap Kinerja Keuangan pada Industri Perhotelan (Studi Kasus Pada Melia Bali Hotel)" Vol. 8. No. 2.Hal 11.

Siswo Suriadi, 7 Mei 2019, Tanggung Jawab Sosial Perusahaan https://id.m.wikipedia.org/wiki/Tanggung_jawab_sosial_perusahaan dipetik 27 Juni 2019.

Sugiyono 2013, Metode Penelitian Kuantitatif Kualitatif dan R\&D. Penerbit Alfabeta. Bandung

Untung, Hendrik B. 2008. Corporate SocialResponsibility. Sinar Grafika.Jakarta

Versa Yunita, 26 Maret 2015, Pelaksanaan CSR bagi Holding Company dan Anak Perusahaan, https://environment-indonesia.com/pelaksanaan-csrbagi- holding-company-dan-anak-perusahaan/ dipetik 30 Juni 2019. 